\title{
Comparative Study of Commercial Oxide Electrodes Performance in Electrochemical Degradation of Organics in Aqueous Solutions
}

\author{
Rosângela L. Pelegrino ${ }^{a}$, Rosana A. Di Iglia ${ }^{a}$, Caio G. Sanches ${ }^{b}$, Luis A. Avaca $^{c}$ and Rodnei Bertazzoli ${ }^{a *}$ \\ ${ }^{a}$ Departamento de Engenharia de Materiais, Faculdade de Engenharia Mecânica, UNICAMP, CP 6122, 13083-970, \\ Campinas - SP, Brazil \\ ${ }^{b}$ Departamento de Térmica e Fluidos, Faculdade de Engenharia Mecânica, UNICAMP, CP 6122, 13083-970, \\ Campinas - SP, Brazil \\ ${ }^{c}$ Instituto de Química de São Carlos, USP, CP 780, 13560-970, São Carlos - SP, Brazil
}

\begin{abstract}
Neste trabalho foi realizado um estudo visando a potencial aplicação de dois eletrodos comerciais tipo DSA ${ }^{\circledR}$ no tratamento eletroquímico de efluentes aquosos. Anodos com composição superficial $70 \mathrm{TiO}_{2} / 30 \mathrm{RuO}_{2}$ e $45 \mathrm{IrO}_{2} / 55 \mathrm{Ta}_{2} \mathrm{O}_{5}$ foram usados num reator de fluxo com densidades de corrente de 15 a $150 \mathrm{~mA} . \mathrm{cm}^{-2}$ e velocidade da solução de $0,24 \mathrm{~m} . \mathrm{s}^{-1}$. Os resultados mostram que fenol e as quinonas são degradados até concentrações muito baixas, embora apenas uma pequena fração seja mineralizada. A partir de uma solução com $100 \mathrm{mg} . \mathrm{L}^{-1}$ de fenol, a $100 \mathrm{~mA} . \mathrm{cm}^{-2}$, após cinco horas de eletrólise foram encontrados $0,4 \mathrm{mg} . \mathrm{L}^{-1}$ de fenol, $1 \mathrm{mg} . \mathrm{L}^{-1}$ de hidroquinona e $7 \mathrm{mg} . \mathrm{L}^{-1}$ de benzoquinona. TOC foi reduzido em $35 \%$.
\end{abstract}

\begin{abstract}
In this paper the potentiality of two types of DSA ${ }^{\circledR}$ commercial electrodes, for electrochemical treatment of effluents, is investigated. Oxide anodes, with nominal composition of $70 \mathrm{TiO}_{2} / 30 \mathrm{RuO}$ and $45 \mathrm{IrO}_{2} / 55 \mathrm{Ta}_{2} \mathrm{O}_{5}$, were used in a flow-cell reactor for the electrooxidation of phenol. Comparative results were presented as phenol concentration decay as a function of electrolysis time, as well as $\mathrm{COD}$ and TOC concentration reduction. The cell reactor was operated at current densities, ranging from 15 to $150 \mathrm{~mA} \mathrm{~cm}^{-2}$ and solution linear velocity was $0.24 \mathrm{~m} \mathrm{~s}^{-1}$. Results reported in this paper showed that phenol and quinones were degraded to a very low concentration, besides only a small portion of the organic carbon is reduced. Starting from $100 \mathrm{mg} \mathrm{L}^{-1}$, after five hours of electrolysis at $100 \mathrm{~mA} \mathrm{~cm}^{-2}$, concentrations reached $0.4 \mathrm{mg} \mathrm{L}^{-1}$ of phenol, $1 \mathrm{mg} \mathrm{L}^{-1}$ of hydroquinone, $7 \mathrm{mg} \mathrm{L}^{-1}$ of benzoquinone and TOC was reduced by $35 \%$.
\end{abstract}

Keywords: electrochemical treatment of effluents, oxide coated electrodes, phenol oxidation

\section{Introduction}

Biological and chemical conventional oxidative treatments of aqueous effluent streams, containing organic compounds, are often efficient in complying with legislation. However, this feature is not enough nowadays, when environmental considerations are permanently present in the agenda. Conventional technology for wastewater chemical treatment, demands transportation, storing and handling of hazardous chemicals and leads to the generation of toxic sludge. On the other hand, biological digestion is a long-term treatment, in large physical areas, that also leads to the generation of non-biodegradable soluble and cellular residues. Furthermore, high molecular

\footnotetext{
* e-mail: rbertazzoli@fem.unicamp.br
}

weight fractions present in some types of aqueous effluents tend to be resistant to biodegradation. These questions apparently are encouraging the adoption of environmentally oriented treatments of aqueous effluents derived from new clean technologies. Societies interested in sustainable development, are focusing the discussion on this environmental problem and industries are not addressing the question of waste minimization and treatment accordingly.

In this field, electrochemistry may offer an attractive alternative for treating aqueous streams containing organic compounds by oxidation, via simultaneous oxygen evolution, at an anode surface. Electrolytic process is probably the most adequate tool in the aqueous effluent treatment, ideally suited to the present age where environmental considerations are always to the fore. ${ }^{1}$ 
Indeed, electrons are the only reactant added to the treatment process.

The key for an efficient electrolytic treatment is strongly based on the anode material choice. High corrosion resistance and physical/chemical stability, under high positive potentials, are the main requests. When properties as above are required, Dimensionally Stable Anodes (DSA ${ }^{\circledR}$ ), as those discovered by Beer in the seventies, are the natural candidates. ${ }^{2,3}$ This designation denotes a class of thermally prepared oxide electrodes where a titanium substrate is covered by metallic oxides. Coatings on titanium include $\mathrm{TiO}_{2}, \mathrm{IrO}_{2}, \mathrm{RuO}_{2}$ and $\mathrm{Ta}_{2} \mathrm{O}_{5}$. Combinations such as $\mathrm{x}\left(\mathrm{TiO}_{2}\right) /$ $\mathrm{y}\left(\mathrm{RuO}_{2}\right)$ and $\mathrm{x}\left(\mathrm{IrO}_{2}\right) / \mathrm{y}\left(\mathrm{Ta}_{2} \mathrm{O}_{5}\right)$ are currently marketed and used as electrodes for the chlor-alkali industry. On the other hand, some $\mathrm{DSA}^{\circledR}$ type oxide electrodes may receive additions of $\mathrm{SnO}_{2}$ and $\mathrm{Sb}_{2} \mathrm{O}_{5}$ in concentrations ranging from minor to main components which increase service life and, eventually, selective catalytic power. ${ }^{4}$

The electrochemical oxidation process is a mediated reaction and occurs via oxygen atom transfer from water in the solvent phase to the oxidation product. The overall processes of anodic oxygen transfer may be represented by the generic reaction: ${ }^{5}$

$\mathrm{R}+\mathrm{xH}_{2} \mathrm{O} \rightarrow \mathrm{RO}_{\mathrm{x}}+2 \mathrm{xH}^{+}+2 \mathrm{xe}^{-}$

where $\mathrm{R}$ is the organic reactant and the $\mathrm{RO}_{\mathrm{x}}$ is the oxidation product. In the extreme case, $\mathrm{R}$ is mineralized according to:

$\mathrm{R}+\mathrm{x} \mathrm{H}_{2} \mathrm{O} \rightarrow \mathrm{x} / 2 \mathrm{CO}_{2}+2 \mathrm{xH}^{+}+2 \mathrm{xe}$

known as combustion reaction.

On DSA ${ }^{\circledR}$ type oxide electrodes, the mechanism proposed for the mediated electrodegradation of organic compounds in aqueous solutions presents, as the first step, the discharge of water which leads to the hydroxyl radical $\left(\mathrm{OH}^{*}\right)$ adsorbed on the electrode surface. ${ }^{6,7}$

$\mathrm{MO}_{\mathrm{x}}+\mathrm{H}_{2} \mathrm{O} \stackrel{\mathrm{k}_{3}}{\longrightarrow} \mathrm{MO}_{\mathrm{x}}\left(\mathrm{OH}^{*}\right)+\mathrm{H}^{+}+\mathrm{e}^{-}$

In a first reaction path, species of $\mathrm{MO}_{\mathrm{x}}-\mathrm{O}\left(\right.$ or $\left.\mathrm{MO}_{\mathrm{x}+1}\right)$ are formed from hydroxyl radicals in the active sites of the $\mathrm{MO}_{\mathrm{x}}$ coating, according to equation:

$\mathrm{MO}_{\mathrm{x}}\left(\mathrm{OH}^{*}\right) \stackrel{\mathrm{k}_{4}}{\longrightarrow} \mathrm{MO}_{\mathrm{x}+1}+\mathrm{H}^{+}+\mathrm{e}^{-}$

Then, this physiosorbed specie oxidizes the organic molecules according to equation:

$\mathrm{MO}_{\mathrm{x}+1}+\mathrm{R} \stackrel{\mathrm{k}_{5}}{\longrightarrow} \mathrm{MO}_{\mathrm{x}}+\mathrm{RO}$
The $\mathrm{MO}_{\mathrm{x}+1}$ specie is also responsible for oxygen evolution, in a competitive process as shown bellow:

$\mathrm{MO}_{\mathrm{x}+1} \stackrel{\mathrm{k}_{6}}{\longrightarrow} \mathrm{MO}_{\mathrm{x}}+1 / 2 \mathrm{O}_{2}$

A second possible reaction path is also considered, in which the organic compound is mineralized as follows:

$\left[\mathrm{MO}_{\mathrm{x}}\left(\mathrm{OH}^{*}\right)\right]_{\mathrm{y}}+\mathrm{R} \stackrel{\mathrm{k}_{7}}{\longrightarrow} 2 \mathrm{y} \mathrm{CO}_{2}+2 \mathrm{y} \mathrm{H}^{+}+2 \mathrm{y} \mathrm{e}^{-}+\mathrm{y} \mathrm{MO}_{\mathrm{x}}$

Combustion reaction, represented by equation (7), is more likely to occur on higher oxygen overpotential surfaces that contain $\mathrm{PbO}_{2}, \mathrm{SnO}_{2}$ or $\mathrm{Sb}_{2} \mathrm{O}_{5}$. However, oxygen also evolves:

$\mathrm{MO}_{\mathrm{x}}\left(\mathrm{OH}^{*}\right) \stackrel{\mathrm{k}_{8}}{\longrightarrow} \mathrm{MO}_{\mathrm{x}}+1 / 2 \mathrm{O}_{2}+\mathrm{H}^{+}+2 \mathrm{e}^{-}$

During the organic oxidation, it is probable that both reaction paths play a role.

In this paper the potentiality of two types of DSA ${ }^{\circledR}$ type commercial electrodes, with traditional applications in the chlor-alkali industry, for electrochemical treatment of effluents is investigated. Oxide anodes, with composition of $70 \mathrm{TiO}_{2} / 30 \mathrm{RuO}_{2}$ and $45 \mathrm{IrO}_{2} / 55 \mathrm{Ta}_{2} \mathrm{O}_{5}$, marketed as $\mathrm{DSA}^{\circledR}-\mathrm{Cl}_{2}$ and $\mathrm{DSA}^{\circledR}-\mathrm{O}_{2}$, respectively, were used in a flowcell reactor for the electrooxidation of phenol. In the experiments reported here, we have not intended to present a phenol oxidation study. Phenol has been chosen, as model compound, due to its well-known mechanism of decomposition $^{8-12}$ and for the great number of papers found in literature dealing with phenol electrodegradation..$^{10-15}$ The main goal was to optimize the cell reactor with respect to current density, and to select the best electrode material for organics oxidation. As we are looking forward to scale up the process, the electrode selection is one of the important decisions to take. We have chosen commercial DSA $^{\circledR}$ electrodes taking into account their availability in sizes and shapes impossible of being obtained in bench scale. A comparative performance study between commercial electrode coatings, traditionally used for chloralkali processes, has not been reported in the literature yet. Furthermore, there is no manufacturer technical information available on the application of their products for electrochemical treatment of industrial effluents containing organic pollutants.

By using the commercial oxide coatings in the flow cell reactor, comparative results were presented as phenol concentration decay as a function of electrolysis time as well as chemical oxygen demand (COD) and total organic carbon (TOC) reduction. 


\section{Experimental}

The flow reactor used in the experiments is sketched in Figure 1. It consisted of two polypropylene end plates (labeled $a$ and $e$ ), a platinum cathode (b), a $4 \mathrm{~mm}$ PP spacer (c) and a DSA ${ }^{\circledR}$ anode (d). This end plate (a) also had the electrolyte entrance at the bottom, and the exit was located at the top of the end plate (e). The spacer was designed to facilitate oxygen bubbles release ${ }^{16}$. Anode plates were supplied by De Nora s.p.a. in Brazil with nominal composition in molar percentage of $70 \mathrm{TiO}_{2} / 30 \mathrm{RuO}_{2}$ and $55 \mathrm{Ta}_{2} \mathrm{O}_{5} / 45 \mathrm{IrO}_{2}$. The electrode area inside the cell was 21.6 $\mathrm{cm}^{2}$. During the experiments the reactor was operated in a batch recirculation mode. The electrolyte was recirculated at a flow rate of $120 \mathrm{~L} \mathrm{~h}^{-1}$ which meant a linear velocity of $0.24 \mathrm{~m} \mathrm{~s}^{-1}$ and $500 \mathrm{~mL}$ of solution were electrolyzed each experiment. The electrooxidation experiments were carried out using a Tectrol 5-20 power supply with applied current densities ranging from 15 to $150 \mathrm{~mA} \mathrm{~cm}{ }^{-2}$. The solutions used for the experiments were prepared using $0.5 \mathrm{~mol} \mathrm{~L}^{-1}$ $\mathrm{Na}_{2} \mathrm{SO}_{4}$ and $\mathrm{H}_{2} \mathrm{SO}_{4}$ for $\mathrm{pH} 4$, in which an average concentration of $100 \mathrm{mg} \mathrm{L}^{-1}$ of phenol was added. All reagents were of analytical grade and did not undergo further purification. Distilled and deionized water was used to prepare all solutions. During the experiments of phenol electrooxidation, the solution leaving the reactor was sampled at predetermined intervals, and the remaining phenol concentration was quantified.

Phenol concentration, as well as hydroquinone and benzoquinone concentrations, the two main hazardous products of phenol oxidation, were determined in a Shimadzu HPLC equipment with a Shin-Pack CLC-ODS

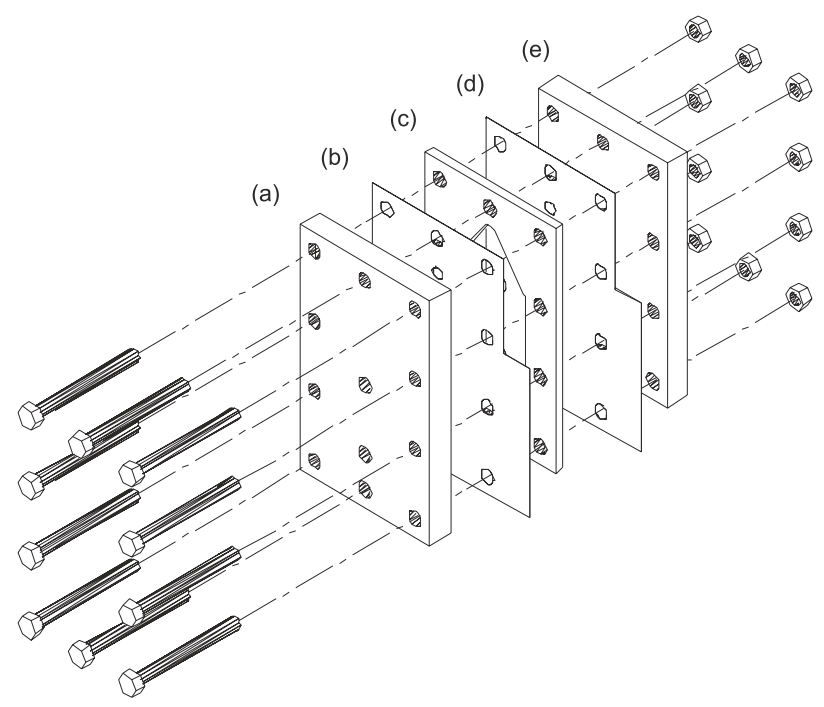

Figure 1. Schematic expanded view of the cell reactor. $a$ and $e$ : end plates. $b$ : platinum cathode. $c$ : spacer. $d$ : DSA ${ }^{\circledast}$ anode. column and a UV-VIS detector, using a wavelength of 265 nm. A U-2000 Hitachi spectrophotometer was used for COD measurements, while TOC values were obtained in a TOC 5000 Shimadzu equipment.

\section{Results and Discussion}

\section{Kinetic study for phenol electrooxidation}

Figure 2 shows profiles of phenol normalized concentration as a function of electrolysis time, for current densities ranging from 15 to $150 \mathrm{~mA} \mathrm{~cm}^{-2}$ and for both types of electrode. As expected, higher current values mean higher phenol electrodegradation rates. However, the $70 \mathrm{TiO}_{2} /$ $30 \mathrm{RuO}_{2}$ electrode performance is markedly superior. As a comparative example, only $35 \%$ of the phenol present in the solution was degraded on the $55 \mathrm{Ta}_{2} \mathrm{O}_{5} / 45 \mathrm{IrO}_{2}$ electrode surface, at $100 \mathrm{~mA} \mathrm{~cm}^{-2}$ in 5 hours, while on the $70 \mathrm{TiO}_{2} /$ $30 \mathrm{RuO}_{2}$ electrode this amount reached $98 \%$ in 3.5 hours of treatment, at the same current density. Actually, two hours of electrolysis were sufficient for $90 \%$ of phenol removal on this electrode surface, at $100 \mathrm{~mA} \mathrm{~cm}{ }^{-2}$; and $3 \mathrm{~h}$ for the same duty at $50 \mathrm{~mA} \mathrm{~cm}^{-2}$. One of the reasons for such a difference in the electrode performance is that the $70 \mathrm{TiO}_{2} /$ $30 \mathrm{RuO}_{2}$ anode should present a higher overpotential for oxygen evolution. This feature makes the electrode material more efficient for oxidation of organic substances. Due to the values of potential in which the electrochemical cell reactor was operated, oxygen evolutions is a simultaneous process to phenol oxidation, and reactions (5) and (7) are responsible only for the oxidation of phenol. Then, the current efficiency depends on how fast reactions (5) and (7)

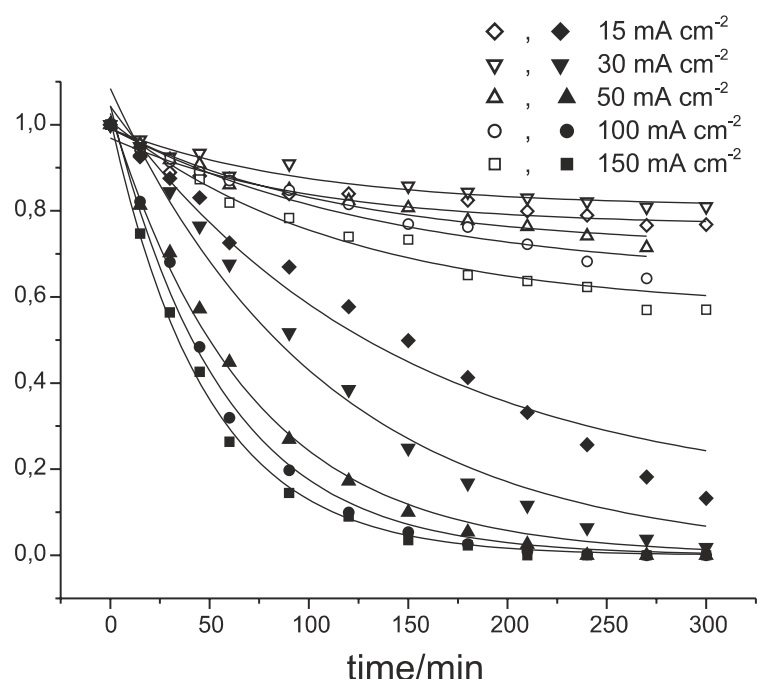

Figure 2. Plot of phenol normalized concentration decay as a function of electrolysis time for the current densities shown. Solid and empty symbols represent the $70 \mathrm{TiO}_{2} / 30 \mathrm{RuO}_{2}$ and $45 \mathrm{IrO}_{2} / 55 \mathrm{Ta}_{2} \mathrm{O}_{5}$ oxide anodes, respectively. 
are when compared to reactions (6) and (8). For organics oxidation, the electrode surface should present $\mathrm{k}_{5}>\mathrm{k}_{6}$ and/ or $k_{7} \gg k_{8}$ in a given potential. In view of the evidences obtained so far, this characteristic is more pronounced on the $70 \mathrm{TiO}_{2} / 30 \mathrm{RuO}_{2}$ electrode surface.

Using data taken from Figure 2, Figure 3 shows plots of $\ln [\mathrm{C}(\mathrm{t}) / \mathrm{C}(0)] v s$. time. Straight lines obtained in these plots are the confirmation of a first order phenol concentration decay during the electrolytic treatment for all the current densities used in this investigation and for both electrode materials, despite the difference in the performance. This linear relationship may be explained by the solution form of the mass balance differential equation, which is:

$$
C(t)=C(0) \exp \frac{k_{P h} A}{V} t
$$

where $\mathrm{C}$ is the time dependent phenol concentration, $\mathrm{A}$ is the anode area $\left(\mathrm{m}^{2}\right), \mathrm{V}$ is the volume $\left(\mathrm{m}^{3}\right)$ of the solution being treated, $t$ is the electrolysis time (s) and $\mathrm{k}_{\mathrm{Ph}}$ is the kinetic constant for phenol oxidation $\left(\mathrm{m} \mathrm{s}^{-1}\right)$. Values of $\mathrm{k}_{\mathrm{ph}}$ were calculated from the slopes of the straight lines in Figure 3. Values of kinetic constants for both electrodes are shown in Figure 4, in which the values obtained on the $70 \mathrm{TiO}_{2} / 30 \mathrm{RuO}_{2}$ anode are twenty times greater than those for the $55 \mathrm{Ta}_{2} \mathrm{O}_{5} / 45 \mathrm{IrO}_{2}$ electrode, in the range of 50 to 100 $\mathrm{mA} \mathrm{cm}{ }^{-2}$. It is interesting to note that by changing current density in one order of magnitude, $\mathrm{k}_{\mathrm{Ph}}$ also increases by one order of magnitude on the $70 \mathrm{TiO}_{2} / 30 \mathrm{RuO}_{2}$ electrode surface. On the other hand, by incrementing current density in one order of magnitude on the $55 \mathrm{Ta}_{2} \mathrm{O}_{5} / 45 \mathrm{IrO}_{2}$ surface, only a modest increase of 2.6 times the $\mathrm{k}_{\mathrm{PH}}$ values is observed, i. e., from $2.710^{-6} \mathrm{~m} \mathrm{~s}^{-1}$ to $7.210^{-6} \mathrm{~m} \mathrm{~s}^{-1}$. The

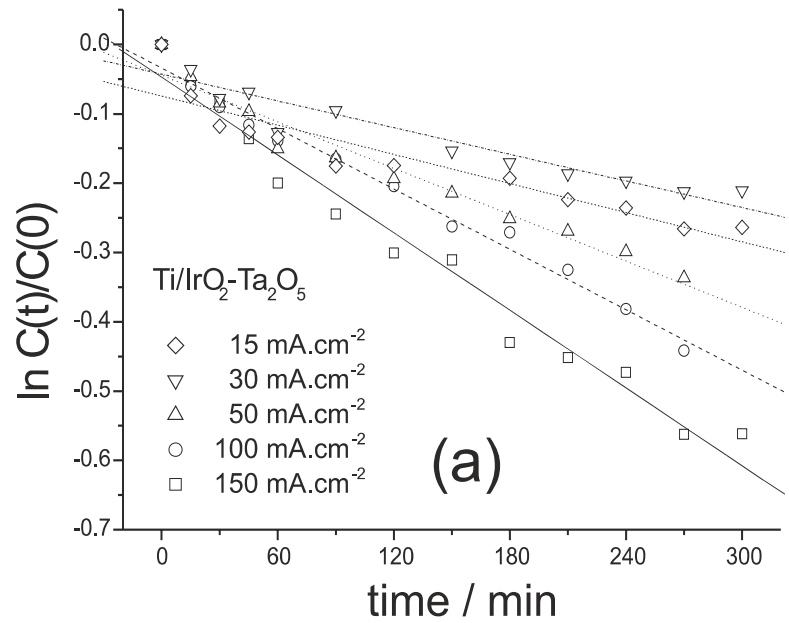

reason for such poor performance for phenol electrooxidation is that any increment in the current density favors the oxygen evolution, represented by equations (6) and (8). This is also the explanation for $\mathrm{k}_{\mathrm{Ph}}$ decreasing on the $70 \mathrm{TiO}_{2} / 30 \mathrm{RuO}_{2}$ anode surface, for current values higher than $100 \mathrm{~mA} \mathrm{~cm}^{-2}$. From this value (or even a bit lower) any extra amount of transferred charge is used for oxygen evolution rather than phenol oxidation.

\section{Phenol oxidation by-products}

According to the literature, benzoquinone and hydroquinone are the main resulting compounds of phenol oxidation prior to organic acid formation, in acidic medium. ${ }^{8,10,11}$ Quinones formation followed by its degradation are evidence of a successful phenol oxidation operation, and also the guarantee for the transformation of the solution into a more biodegradable product. On the other hand, reduction of TOC values is an evidence of organics combustion or mineralization.

Figure 5 presents the hydroquinone and benzoquinone concentration profiles along electrolysis time using current density of $100 \mathrm{~mA} \mathrm{~cm}{ }^{-2}$, for both electrode materials. As a result of the poor performance presented by the $55 \mathrm{Ta}_{2} \mathrm{O}_{5} /$ $45 \mathrm{IrO}_{2}$ electrode, low levels of quinones were formed during electrolysis. However, the concentrations were always increasing and no sign of quinones degradation was observed. On the other hand, on the $70 \mathrm{TiO}_{2} / 30 \mathrm{RuO}_{2}$ electrode, quinones concentration increased steeply during the early moments of electrolysis and started to decrease until lower values than those present in the initial solution were reached. After five hours of electrolysis, at $100 \mathrm{~mA}$ $\mathrm{cm}^{-2}$, concentrations reached $0.4 \mathrm{mg} \mathrm{L}^{-1}$ of phenol (see Figure 2), $1 \mathrm{mg} \mathrm{L}^{-1}$ of hydroquinone and $7 \mathrm{mg} \mathrm{L}^{-1}$ of benzoquinone.

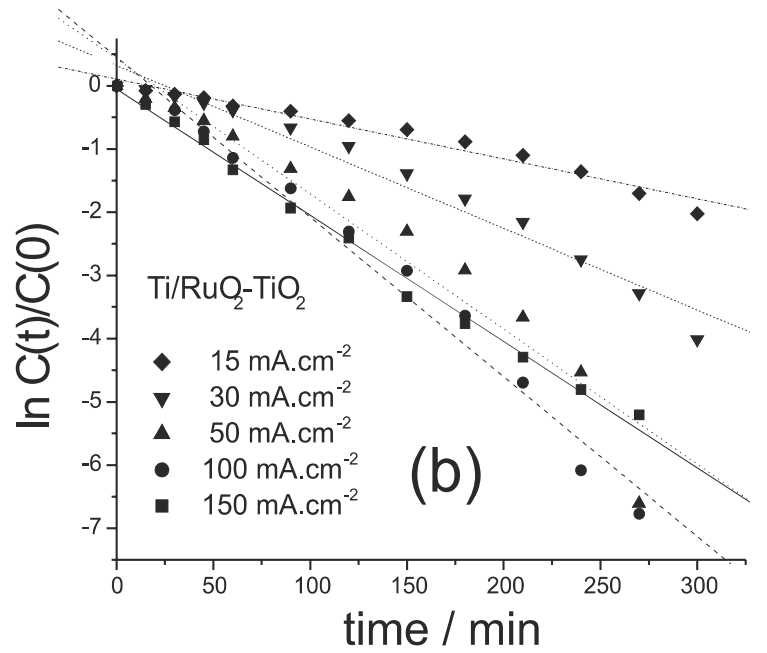

Figure 3. Logarithm of normalized concentration decay for the $45 \mathrm{IrO}_{2} / 55 \mathrm{Ta}_{2} \mathrm{O}_{5}$ and for the $70 \mathrm{TiO}_{2} / 30 \mathrm{RuO}_{2}$ electrodes. Solid and empty symbols represent the $70 \mathrm{TiO}_{2} / 30 \mathrm{RuO}_{2}$ and $45 \mathrm{IrO}_{2} / 55 \mathrm{Ta}_{2} \mathrm{O}_{5}$ oxide anodes, respectively. 


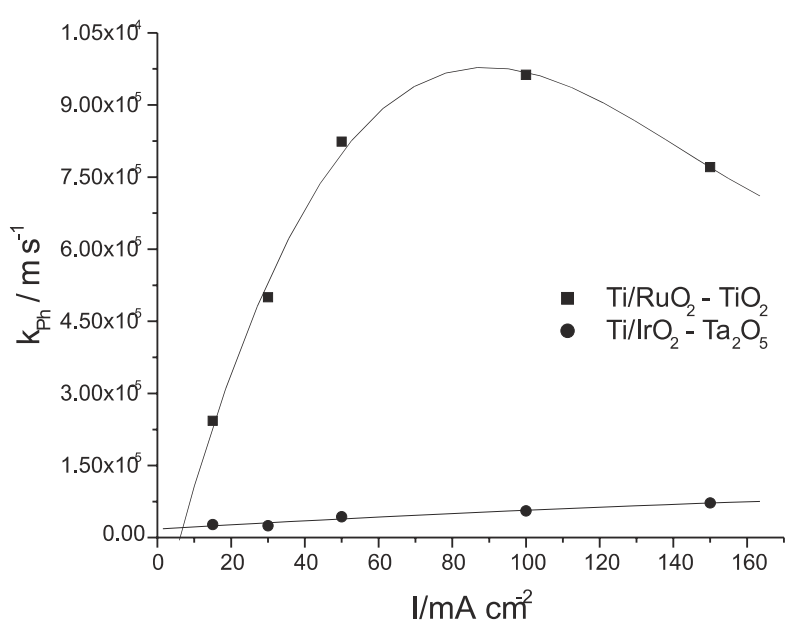

Figure 4. Kinetic constant for phenol electrooxidation as a function of current density for both electrodes. Calculated using data from figure 3 and equation (9).

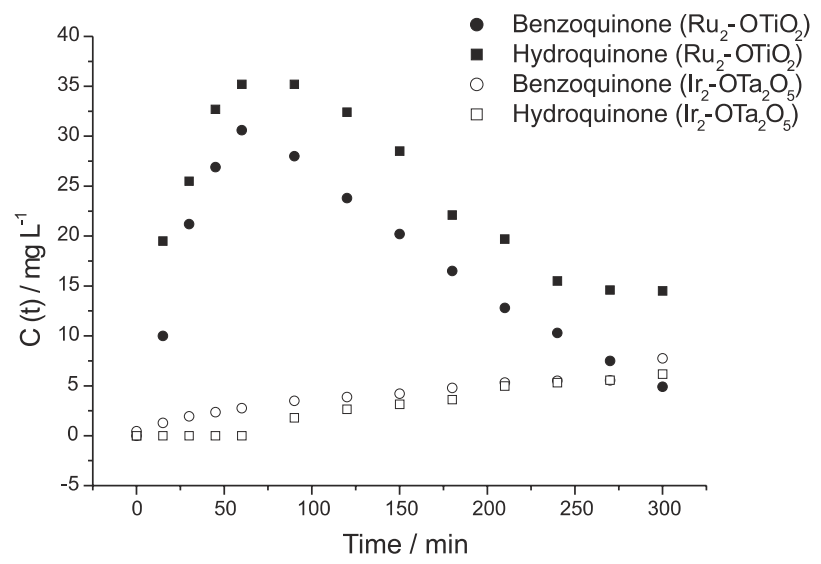

Figure 5. A comparison between quinones concentration profiles during electrolysis at $100 \mathrm{~mA} \mathrm{~cm}^{-2}$ for both electrodes.

However, only a small fraction of the organic compounds were actually mineralized. Figure 6 shows data for TOC and COD degradation as a function of applied current density, for $5 \mathrm{~h}$ of electrolysis. As expected, a higher percentage of TOC and COD removal were observed on the $70 \mathrm{TiO}_{2} / 30 \mathrm{RuO}_{2}$ electrode. Following the same behavior of the $\mathrm{k}_{\mathrm{Ph}}$ values, degradation rates of TOC and COD reached a maximum and decreased from current density of $100 \mathrm{~mA} \mathrm{~cm}{ }^{-2}$. TOC and COD reduction is always a challenge to the conventional biodegradation treatments and such a feature is not different to the electrochemical treatment. Despite the low final concentration values of phenol and of quinones, small amounts of these were mineralized and only $35 \%$ of the initial TOC was degraded. This may be an indication that the process, depicted by equation (4), and the following steps, represented by equations (5) and (6), are mandatory in the electrochemical process of aqueous effluents treatment, rather than the combustion represented by equations (2) and (7).

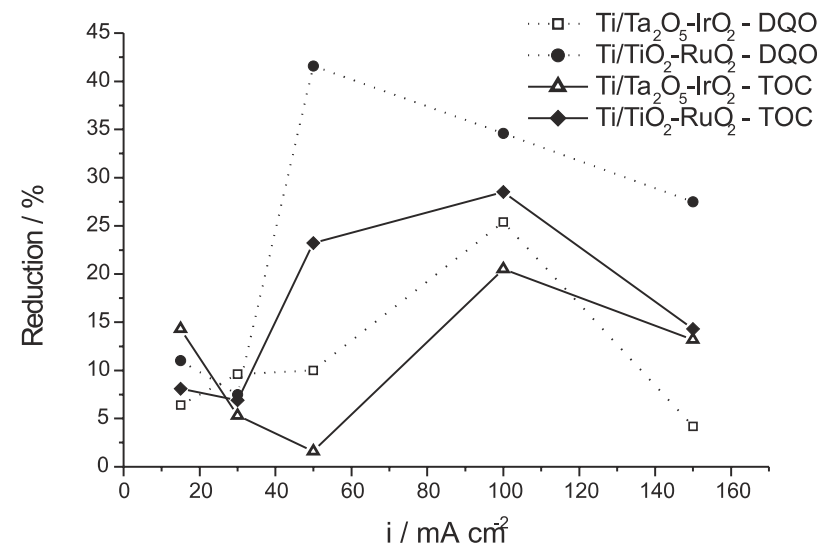

Figure 6. Reduction profile of total organic carbon (TOC) and chemical oxygen demand (COD) as a function of current density for both electrodes.

\section{Energy consumption for phenol oxidation}

Accessing the current efficiency of the eletrooxidation process is a difficult task, since it does not occur as an usual electron transfer reaction. Current efficiency (E) may be estimated by the ratio between the oxygen evolution rate in the presence and in the absence of phenol in solution, ${ }^{7}$ and it may be written as:

$$
E=\frac{k_{m}[R]}{k_{m}[R]+k_{n}}
$$

where $\mathrm{m}=5$ or 7 and $\mathrm{n}=6$ or 8 , depending on the reaction path, with $k_{m}$ and $k_{n}$ being highly dependent on the oxide electrode coating and on the applied potential.

As it seems that all the processes, the reactions of which are depicted by equations (3)-(8), play a role, it is difficult to decide which is the best criterion for current efficiency calculation. However, for electrode performance comparison, the energy consumed per kilogram of phenol degraded during the electrolysis may also be a good criterion to decide whether or not electrooxidation is a feasible process. Energy consumption calculations may be useful for cost estimating, and for the decision of which is the best working current density on which electrode material. Figure 7 shows values of energy consumed for the degradation of one kilogram of phenol for the current densities used in the experiments. Values shown in the vertical axis were calculated by multiplying applied voltage between the cathode and the anode electrodes, current (kA) and the electrolysis time (h). By comparing the straight lines in Figure 7, energy spent on the $55 \mathrm{Ta}_{2} \mathrm{O}_{5} / 45 \mathrm{IrO}_{2}$ electrode is practically twice the amount used for phenol oxidation on the $70 \mathrm{TiO}_{2} / 30 \mathrm{RuO}_{2}$ anode. Considering the 


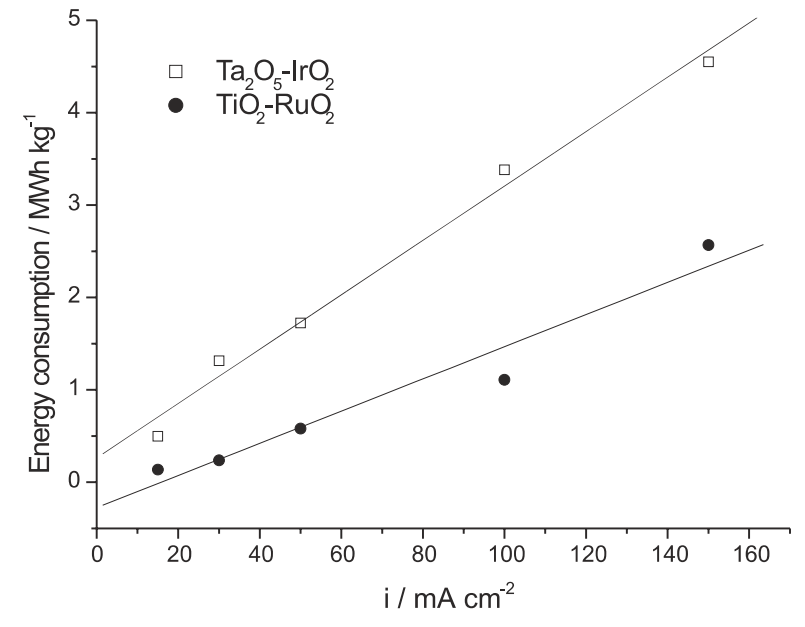

Figure 7. Energy consumption for each kilogram of phenol oxidized. Values over the experimental points are the percentage of phenol degraded after five hours of electrolysis at the current densities shown.

results shown in Figure 2, three hours of electrolysis were sufficient for $90 \%$ of the phenol degradation at $50 \mathrm{~mA} \mathrm{~cm}{ }^{-2}$ on the last electrode. In this operation, a net current of 1.08 A was reached under a potential of 5 Volts. Taking these parameters into account, energy consumption calculations lead to a value of $300 \mathrm{kWh} \mathrm{kg}^{-1}$. Considering the industrial $\mathrm{kWh}$ average value in Brazil of US\$ 0.02 , US\$ 6.00 is the cost for the degradation of $1 \mathrm{~kg}$ of phenol. In the case of a $100 \mathrm{mg} \mathrm{L}^{-1}$ phenol solution, $10,000 \mathrm{~L}$ can be treated at this price. It is still high when compared to the conventional biodegradation treatment, and much has to be done towards looking for a more efficient and less expensive process. However, some advantages arise from the electrochemical treatment, which are:

1. Reduction of man hours in controlling the process, since it can be easily automated;

2. Reduction in treatment time. Electrodegradation takes a couple of hours whereas biodegradation may take more than a week;

3. It is a non-sludge generating process.

\section{Conclusions}

Electrochemical phenol oxidation occurs on both, $70 \mathrm{TiO}_{2} / 30 \mathrm{RuO}_{2}$ and $45 \mathrm{IrO}_{2} / 55 \mathrm{Ta}_{2} \mathrm{O}_{5}$ oxide anodes, in an acidic medium, using current densities ranging from 15 to $100 \mathrm{~mA} \mathrm{~cm}^{-2}$ and solution linear velocity of $0.24 \mathrm{~m} \mathrm{~s}^{-1}$. Phenol electrooxidation and quinones formation/degradation rates are markedly superior to the first one. Values of kinetic constant recorded as a function of current density showed that phenol oxidation rates increase steeply until $50 \mathrm{~mA} \mathrm{~cm}$ ${ }^{2}$, still increasing at a slower rate until $100 \mathrm{~mA} \mathrm{~cm}^{-2}$, and after that start to decrease. Results reported in this paper showed that phenol and quinones are degraded to very low concentrations, and a small portion of the total organic carbon is reduced, producing clear evidence that a mixed process of combustion (equation 7) and of selective oxidation (equations 5) takes place. After five hours of electrolysis, at $100 \mathrm{~mA} \mathrm{~cm}^{-2}$, concentrations reached $0.4 \mathrm{mg} \mathrm{L}^{-1}$ of phenol, $1 \mathrm{mg} \mathrm{L}^{-1}$ of hydroquinone and $7 \mathrm{mg} \mathrm{L}^{-1}$ of benzoquinone. However, only $35 \%$ of TOC were reduced. These results, and the costs involved in the electrochemical treatment, show the need of the integration of a biological and electrochemical oxidation processes for wastewater treatment. The electrochemical treatment could be used for the oxidation of refractory compounds and higher molecular weight fractions, followed by biological mineralization.

\section{References}

1. Rajeshwar, K.; Ibanez, J. G. In Environmental Electrochemistry: Fundamentals and Applications in Pollution Sensors and Pollutant Treatment, Academic Press, USA, 1997.

2. Beer, H. B.; US pat. 3, 632, 498, 1972.

3. De Nora, O.; Nidola, A.; Trisoglio, G.; Bianchi, G.; Br. pat. 1, 399, 576, 1973.

4. Correa-Lozano, B.; Comninellis, Ch.; De Battisti, A.; J. Appl. Electrochem. 1997, 27, 970.

5. Savall, A.; Chimia 1995, 49, 23.

6. Fóti, G.; Gandini, D.; Comninellis, Ch.; Curr. Top. Electrochem. 1997, $5,71$.

7. Simond, O.; Schaller, V.; Comninellis, Ch.; Electrochim. Acta 1997, 42, 2009.

8. Flezsar, B.; Ploszynska, J.; Electrochim. Acta 1985, 30, 31.

9. Iotov, P. I.; Kalcheva, S. V.; J. Electroanal. Chem. 1998, 442, 19.

10. Gattrell, M.; Kirk, D. W.; Can. J. Chem. Eng, 1990, 68, 997.

11. Comninellis, Ch.; Pulgarin, C.; J. Appl. Electrochem. 1991, 21, 703 .

12. Kotz, R.; Stucki, S.; Carcer, B.; J. Appl. Electrochem. 1991, $21,14$.

13. Awad, Y. M.; Abuzaid, N. S.; Sep. Sci. Technol. 1999, 34, 699.

14. Comninellis, Ch.; Nerini, A.; J. Appl. Electrochem. 1995, 25 , 23.

15. Comninellis, Ch.; Pulgarin, C.; J. Appl. Electrochem. 1993, 23,103 .

16. Wu, W. S.; Rangaiah, G. P.; J. Appl. Electrochem. 1993, 23, 113.

Received: January 23, 2001

Published on the web: November 8, 2001

FAPESP helped in meeting the publication costs of this article. 